new Text-Book and defended in the Bulletin. ${ }^{1}$ It is but fair also to recognize, in this connection, the views of Max Meyer, H. Ebbinghaus, and others, who have by no means admitted the conclusiveness for middle-ear origin of combination tones of the experiments of Schaefer and Waetzmann.

BRTGHAM YOCNG UNIVHRSITY,

Joseph Peterson. PROVO, UTAH.

Let us be clear as to what we are discussing! In his paper of last November, Professor Peterson affirmed that a statement in my Textbook showed a complete misapprehension of the trend of recent investigation; that I cited no literature; that the work of Dennert and Bingham seemed to him 'to overthrow completely' the Helmholtzian theory; and that he himself had suggested a modification of that theory "which aims to avoid the objections which are fatal to the drum-ossicles explanation, and which has certain other advantages." I replied that Mr. Peterson had been anticipated in his suggestion; ${ }^{2}$ that Schaefer had furnished a theoretical answer to the inference drawn from the work of Dennert and Bingham; that the first literary

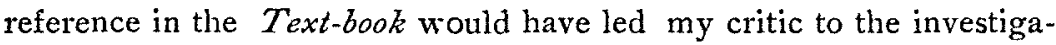
tions upon which I relied; and that these investigations, which $\mathrm{Mr}$. Peterson had apparently overlooked, did in fact justify the Text-book statement. This is all, surely, straightforward enough. We are discussing a statement made not later than May I, I909, the date of my preface, and the question is whether the statement is, for purposes of undergraduate instruction, adequate to the facts as known at that time. I have tried to show that it is ; and I rest my case. ${ }^{3}$

In his present communication, however, Mr. Peterson has shifted the issue. He has gone behind the Text-book statement, which (as I said before) occurs in a chosen theoretical context; I could no more discuss the views of Max Meyer and Ebbinghaus, worthy of consider-

${ }^{1}$ Because of my criticism of his statement, Professor Titchener assumes that I have not read Nagel's Handbuch to which reference is made in my monograph. The Weismannian arguments for non-transmission of acquired characters illustrate the point that 'facts ' or 'evidences' are not independent of their meaning.

${ }^{2}$ Not by Waetzmann alone, but by Schaefer also (Arch. f.d.ges. Physiol., I.XXVIII., I899-I900, 524).

${ }^{3}$ There are, of course, some details of Mr. Peterson's present writing that should be cleared up; but I cannot task the patience of the readers of the Bux,ETIN by threshing them out. My critic would probably grant that they are not of primary importance to our discussion. 
ation as they are, than I could discuss those, say, of Wundt or Hermann. He has gone around the statement; for the question of bone conduction, important in its own place, is wholly irrelevant to the matter originally in dispute. And he has gone ahead of it; for he assumes that I hold in May, rgro, to what I published in May, rgog. "The question of the real origin of these tones," he says, " is usually regarded as still open." Personally, I have never regarded it as closed, though I have more than once imagined - probably in common with others - that it was near to closing. That is what I thought a year ago, for the reasons given: I now have reasons, positive and negative, for thinking otherwise. Mr. Peterson has all the right in the world to discuss the general topic of subjective combinational tones, but he surely has no right to shift the ground of controversy, without warning, from the special to the general; a single month may put a text-book statement out of date. ${ }^{1}$

I can hardly close without a reference to Mr. Peterson's charge of " needless and ungrounded speculation, indulged in solely to support a personal theory." The facts are these : the theory is not mine, but Schaefer's; I said that "it struck me as reasonable";" and, as Schaefer had not gone into details, I outlined in a foot-note the way in which I conceived it to work.

E. B. Titchener.

\section{GALVANOMETRIC DEFLECTIONS WITH ELECTRODES APPLIED TO THE ANIMAL BODY.}

The recent article by Dr. Sidis (I) on the so-called psycho-galvanic phenomena is in some respects so remarkable as to warrant the consumption of the BuLletiv's space and the readers' time in criticism thereof. The fact that Sidis' work is typical of all that has been done in this line of experimentation gives us still more justification.

Dr. Sidis claims that the results obtained by other experimenters in psycho-galvanism can be explained as due $(a)$ to variations in the

${ }^{1}$ May I give another illustration in this same field ? A year ago the formant theory of the timbre of certain musical instruments was well to the front; to-day we have Köhler's work, and the status of the formant theory is altogether doubtful. What is the text-book writer to do? What can he do, but try to reflect the condition of knowledge at the time of writing?

${ }^{2}$ Stumpf now takes the same position. "Dass das Trommelfell für die Bildung der Kombinationstöne nicht unentbehrlich ist, wie aus der schönen Untersuchung Binghams m. E. zwingend hervorgeht, berührt gleichfalls nicht das Wesentliche. Es könnte statt des Trommelfells inmer noch eine andere asymmetrische Membran oder es könnten asymmetrische knöcherne Teile herangezogen werden" (Zeits.f. Psychol., LV., I910, I39). 